\title{
Lusioersily
}

\section{Meeting the needs of vulnerable young men: a study of service provider views}

Jim, C., Rondon-Sulbaran, J., Galway, K., \& Leavey, G. (2011). Meeting the needs of vulnerable young men: a study of service provider views. Children \& Society, 27, 60-71. https://doi.org/10.1111/j.1099-0860.2011.00372.x

Link to publication record in Ulster University Research Portal

\section{Published in: \\ Children \& Society}

Publication Status:

Published (in print/issue): 01/01/2011

DOI:

10.1111/j.1099-0860.2011.00372.x

\section{Document Version}

Publisher's PDF, also known as Version of record

\section{General rights}

Copyright for the publications made accessible via Ulster University's Research Portal is retained by the author(s) and / or other copyright owners and it is a condition of accessing these publications that users recognise and abide by the legal requirements associated with these rights.

\section{Take down policy}

The Research Portal is Ulster University's institutional repository that provides access to Ulster's research outputs. Every effort has been made to ensure that content in the Research Portal does not infringe any person's rights, or applicable UK laws. If you discover content in the Research Portal that you believe breaches copyright or violates any law, please contact pure-support@ulster.ac.uk. 


\title{
Exploring the Needs of Socially Excluded Young Men
}

\author{
Janeet Rondón* ${ }^{\dagger} \dagger$, James Campbell\$, Karen Galway $\uparrow$ and Gerard Leavey $\uparrow$ \\ $\dagger$ Centre for Mental Health Research, Northern Ireland Association for Mental Health, Belfast, UK \\ tDepartment of Social, Therapeutic and Community Studies, Goldsmiths, University of London, \\ London, UK
}

In recent years, social exclusion has gained the attention of governments around the world. This paper reports on a qualitative study involving 27 young men aged 14-19 years experiencing particular forms of exclusion in the context of Northern Irish society. The study used a focus group methodology to elicit their views with the aim of exploring both emotional and psychological needs and the structural factors that may contribute to their experiences of social exclusion. The findings reveal a range of unmet social and psychological needs, the impact of sectarianism and segregation, and a paucity of support systems in place. The paper concludes by making recommendations about how policy-makers and practitioners could find more imaginative ways of engaging such vulnerable young men to reduce social exclusion. (c) 2012 The Author(s) Children Et Society (C) 2012 National Children's Bureau and Blackwell Publishing Limited

Keywords: mental health promotion, Northern Ireland., social exclusion, young men.

\section{Introduction}

Policy-makers in the United Kingdom (UK) are increasingly concerned about the adverse outcomes of social exclusionary processes on young people such as unemployment, ill health (physical and mental), substance abuse and antisocial behaviour (Cabinet Office, 2006). Government responses are varied; for example, there have been attempts to criminalise antisocial behaviour using antisocial behaviour orders (Directgov, 2010). Furthermore, disengaged 16-19 year-olds have been encouraged to continue in education through the introduction of the educational maintenance allowance (EMA) in 2004, a financial incentive designed to promote inclusion of students facing economic hardship. The EMA was discontinued in 2011 and replaced with bursary funds, the administration, allocation and conditions for which have been devolved to further education institutions (Directgov, 2012). Historically, authors have expressed concerns that there has not been a 'joined up' approach to addressing the needs of children and young people (Bradshaw, 2011), despite the aspirations of policy-makers.

The concept of social exclusion is contested with a variety of definitions used in the literature (Webster and others, 2004). In this paper, we have used the definition by Levitas and others (2007, p. 9) who argue that social exclusion is:

... a complex and multi-dimensional process. It involves the lack or denial of resources, rights, goods and services, and the inability to participate in the normal relationships and activities, available to the majority of people in a society, whether in economic, social, cultural or political arenas. It affects both the quality of life of individuals and the equity and cohesion of society as a whole. 
This definition fits the current context due to the emphasis on process issues and multiple deprivation. The participants in the current study are at risk of experiencing exclusions such as teenage pregnancy, school exclusion, lack of skills, unemployment, family breakdowns, alcohol dependency, homelessness and imprisonment (Cabinet Office, 2001). The interlinked nature of these social inequalities requires a holistic approach utilising joined-up services that can facilitate multi-dimensional approaches.

\section{Social exclusion in Northern Ireland}

Different types of social exclusion affect children and young people in Northern Ireland (NI), as in other parts of the UK. There are high levels of child poverty (New Policy Institute, 2009) and under-educational achievement in deprived areas (Bayliss and Sly, 2009). In addition, youth unemployment in NI mirrors that of the UK, with 6.8 per cent unemployment across all ages, rising to 18.4 per cent in 18-24 year-olds (Northern Ireland Statistics and Research Agency, 2011); UK figures are currently 7.8 per cent and 20.4 per cent respectively (Office for National Statistics, 2011). One obvious area of difference between NI and the rest of the UK has been the impact of political conflict sparking considerable debate about how much this has affected the lifestyles and social and economic opportunities for young people (McAlister and others, 2009). Low-income neighbourhoods have experienced less socioeconomic progress than others in the UK due, in part, to the intermittent nature of the political process and the ongoing sectarian divisions, which limit opportunities for cross-sectoral anti-poverty initiatives (Davidson and Leavey, 2010; McCormick and Harrop, 2009). This inequality is heightened by a segregated school system divided on the basis of religion where only $6.4 \%$ of the total enrolment in compulsory education attends integrated schools (Department of Education, 2010).

Although there is growing awareness of the problems of children and young people in NI following the Good Friday Agreement (Northern Ireland Office, 1998), many still have to navigate their transition to adolescence through to adulthood amidst continuing legacies associated with past violence or contemporary issues of sectarianism and segregation (McAlister and others, 2009; McGrellis, 2005). Experiences of sectarianism and social exclusion are inevitable and nuanced. Researchers have explored factors of resilience and vulnerability that help explain behaviours and social practices. For example, Lloyd and others (2008) have argued that most children and young people may not have been adversely affected psychologically as might be expected, whereas Leonard (2010) argues that it may be that young people exhibit a mix of responses, sometimes reinforcing the sectarianism of divided communities, whilst at other times demonstrating resilience and resistance. It has also been suggested that young people may be more likely to be involved in antisocial activity, substance misuse and aggression (O'Reilly and Stevenson, 2003). A number of authors have explored the ways in which such behaviours can be understood in terms of gender differences. Thus, McGrellis (2005) has speculated that perceptions of masculinity inform the actions of some young men, and Hargie and others (2001) suggest that, unlike young men, young women were more likely to traverse sectarian boundaries and also to self-disclose their worries about life. Other research on the psychological impact of the conflict has shown that adolescents' exposure to direct and indirect violence has been detrimental to their mental health and well-being (MacAloney and others, 2009), leading to negative coping mechanisms such as denial (O'Reilly and Stevenson, 2003). Meanwhile high levels of psychological and mental health needs often remain unmet by health and social care services (Campbell and others, 2011; McAlister and others, 2009). 
As a result of these deep-seated structural problems, there is growing concern about elevated levels of suicide amongst young people in NI. For example, the suicide rate for younger men (age 15-24) doubled between 1995 and 2000 - to over 30 per 100000 (Tomlinson, 2007b). Between 2000 and 2004, there were approximately 150 suicides each year, compared to nearly twice this rate in 2005 when 213 incidents were recorded (Haydon and Scraton, 2008). After decades of relative stability, NI has seen suicide rates increase by 64 per cent over a 10-year period since 2000, with the latest figures sitting at 313 deaths registered in 2010. Most of the rise can be attributed to an alarming increase in deaths of young men in the 15-34 age group with a disproportionate rise in disadvantaged areas, bringing to the fore the deprivation gap (Department of Health, Social Services and Public Safety, 2010a). This notable rise in suicide prompted the development of a suicide prevention strategy — Protect Life: A Shared Vision (Department of Health, Social Services and Public Safety, 2006) — which has funded both a national telephone helpline and community-based initiatives for the prevention of suicide at a cost of over $£ 6 \mathrm{~m}$ per annum. Recent anecdotal feedback from local communities that 'existing services and programmes are undoubtedly saving lives' (Department of Health, Social Services and Public Safety, 2010a, p. 10) sits alongside a recent review of the evidence base for Protect Life, which has recommended that systematic evaluation of many actions within the strategy need to be prioritised due to the limited research evidence available (Department of Health, Social Services and Public Safety, 2010b). Despite the continuing increase in suicide rates since 2006, as well as the challenges involved in robustly evaluating suicide prevention initiatives, the Protect Life Strategy has been extended for a further period of four years (Department of Health, Social Services and Public Safety, 2010a).

To sum up, it is important to draw together some themes underpinning the social exclusions that affect young people across the UK and specifically in NI. Earlier studies of the experience of young people in NI focused on the pathways of working-class youth from school to the labour market confirmed that, like their UK counterparts, their lives were framed by structures of educational inequality and the perils of a declining labour market (Jenkins, 1983). Bell (1987), whilst acknowledging the importance of using this analytical notion of working-class youth lifestyles, argued that there was a failure to recognise the impact of sectarian division and how youth cultural 'lifestyles' sustained and reproduced the adverse consequences of this impact. Recent studies (Tomlinson, 2007a) have indicated that for young men, particularly in working-class areas, 'the troubles' (as the conflict is commonly referred to) in NI have generated highly localised social structures where paramilitary and criminal violence, intimidation and bullying are thought to have contributed to suicide and harmful behaviours.

The following study was designed to examine the experiences and needs of vulnerable young men living in NI, given the social and economic contexts described above. Answers to three key questions were sought: what are the social and emotional needs of young men? to what extent do communities and the wider society respond to those needs? and what are the challenges involved, and the barriers to providing appropriate and accessible services for young men?

\section{Methods}

\section{Setting}

The research area comprises five local government districts (LGDs) with a population of over 300000 people, of whom 32 per cent are aged below 20 years. Most of the population lives 
in socially deprived rural areas - three of the five LGDs in this area are ranked among the top ten most deprived districts in NI (Northern Ireland Statistics and Research Agency, 2010). Changes in the labour market have seen job shortages in the local economy as well as an influx of migrant workers, particularly from Eastern European countries. This change in demographics has brought to the surface an increasing problem of racial tensions adding to the existing and ongoing sectarian tensions prevailing in NI (South Tyrone Empowerment Programme, 2006).

\section{Participants}

Twenty-seven young male participants aged between 14 and 19 years (mean 16 years-old) were recruited. Written consent was obtained from parents for those participants under 16 years-old. The sample included young men who were either in full- or part-time education ( $n=19$ ) or employed $(n=4)$; four participants did not disclose any educational, training or employment activity $(n=4)$.

A wide range of statutory, community and voluntary agencies delivering services to young men in this geographical area were identified through a mapping exercise and subsequently contacted and invited to participate. The identified organisations, directly working with vulnerable young men deemed to be at risk and vulnerable in terms of a range of health, social care and educational factors, were asked to assist in the recruitment of the sample. The difficulties in accessing 'hard to reach' groups as well as the potential bias of some of the approaches used are well known (Faugier and Sargeant, 1997; Griffiths and others, 1993; Jones and Allebone, 1999). A snowball sampling approach was used to generate a sample (Becker, 1963; Tastsoglou and Miedema, 2003). Although respondents were not specifically recruited according to any risk vulnerability criteria, the aim was to target young men who were most vulnerable to processes of exclusion, intimidation and at risk of poor mental health, self-harm and suicide.

\section{Data collection}

Focus group interviews were used to collect data. This is a flexible, appropriate and useful method for generating a range of views, beliefs and attitudes relatively quickly. In focus groups, spontaneous conversation is encouraged (Finch and Lewis, 2008) with individuals sharing similar characteristics or experiences who fully cover a limited number of issues in a detailed manner (Hennink and Diamond, 1999). A total of five focus group interviews (40-50 min) took place at venues familiar to the participants. Three groups comprised young men participating in community-based programmes supported by community, voluntary or statutory agencies — Adolescent Partnership (AP), Young Persons' Project (YPP) and the Youth Service (YS). Two groups included young men in full-time education post-primary school (PS) and education other than at school (EOTAS). Before the focus groups took place, participants were asked to complete a brief questionnaire that was used to collate information about age, current employment, educational status and geographical base. Although religious identity was not sought (for concerns of the safety of participants), the geographical catchment areas of projects enabled some estimate about breakdown of religious identities of participants: the YS groups were run in mainly Catholic, Nationalist areas, the EOTAS participants attended both Protestant and Catholic educational facilities, and the AP and YPP were health and social care services provided to both communities. 
The topic guide comprised mostly open-ended questions to encourage participants to engage in discussion and express their views, feelings and thoughts freely. At the end of the focus group, participants were given the opportunity to comment on any other issues that had not been covered. Examples of the questions asked include: "what is it like being a young man in the area?', 'what sort of problems do young men face?' and 'when young men have problems who or where do they go to for help?'

The interviews were audio-recorded with the permission of the participants obtained in written form; occasional notes were taken to complement the analysis of transcribed data.

\section{Data analysis}

The interviews were transcribed and then audio-checked by the researchers for discrepancies and mistakes. They were then entered into a software package for qualitative analysis (ATLAS-ti 4.2), which is helpful for data management and retrieval. The data were analysed through thematic analysis generating codes, which were categorised into key themes (Glaser and Strauss, 1967). The thematic codes were scrutinised separately by each researcher for internal reliability (LeCompte and Goetz, 1982). Competing and complementary themes were distinguished allowing the researchers to arrive at the six key themes described in the findings.

\section{Ethical issues}

Ethical approval for the study was granted by the Northern Ireland Office Research Ethics Committee (NIR03).

\section{Findings}

The analysis of data revealed six themes: exclusion and substance misuse; crime, violence and sectarianism, school and work, help-seeking behaviour, concerns about suicide and suggestions for change.

\section{Exclusion and substance misuse}

A consistent theme that emerged in many of the interviews was a sense of rootlessness, often associated with limited social activities, formal group and leisure facilities. Where such facilities were available, they were sometimes judged to be not age-specific enough, or some young men had already been banned from attending because of their antisocial behaviour. As one of the young men group (YS) put it, where they lived was 'just a dark, dark place'. In a number of focus group interviews, the phrase 'it's boring, there's nothing to do' was commonly used.

The lack of leisure facilities and social activities was often used by the young men to explain or excuse how they used drugs and alcohol. The majority of the interviewees claimed that they were frequent users of alcohol, and binge drinking appeared to be a regular activity, particularly at weekends. While alcohol consumption seemed to be a socially accepted behaviour, participants were less likely to be open about their involvement with drugs. In general, drugs were associated with a different type of young men - more vulnerable and susceptible individuals. 
... if you were getting $\mathrm{p}^{* * * *} \mathrm{~d}$ off real bad in school you could get the odd person who would turn

to drugs; it might help them. (EOTAS group)

In addition, perhaps because of the social opprobrium associated with drug use, most of the respondents denied such involvement. For those who admitted being involved with drugs, there were risks from sinister groups - the young men sometimes described them as paramilitaries or 'hoods'.

If you don't have the money to pay [drug debt] off ... after a week, that's it - they don't give you any more chances. Come and get your house and burn it down. (YPP group)

\section{Crime, violence and sectarianism}

The binge drinking previously described seemed to act as a catalyst for a variety of antisocial behaviours, often with a sectarian edge, which usually escalated to criminal activity, fights and violence. Some of the young men acknowledged that they also became involved in violence with the small number of ethnic minority communities in the area. Crime and violence appeared to be associated with the excitement and the thrill that was opposite to the boredom of everyday life. There were references to frequent minor offences and vandalism such as 'smashing windows'. The respondents also listed a range of violent and risky behaviours, varying in their degree of seriousness as recounted by some of the participants.

Steal a car, get the cops after you, take the number plate off it, paint the car, spray the car and they won't recognise it and burn it. (EOTAS group)

My brother gets beat up every week ... It's just him being a hard man going out fighting every week. (PS group)

The young men spoke of drinking and fighting with 'mates', of not going down town 'if you're in the wrong gang', with the gangs being distinguished by 'religion or where you're from'. One young man reflected the concerns and fears of young Catholics who trespass demarcated spaces.

There is a Protestant side of [town]. If I walked in there I would get my kneecaps done in. (EOTAS group)

The criminal activity described by the young men appeared to assist them in challenging authority figures, particularly the police. The general perception was that the police were more interested in challenging rather than protecting them.

If we see the police we would throw an old brick or two. Everyone hates them! There's barely anybody who likes them ... They're murderers too. They kill people for nothing'. (EOTAS group)

\section{School and work}

Many of the participants in the study reported poor experiences of school and were pessimistic about work opportunities and the precariousness of the labour market in the area. They referred to declining opportunities in education that limited their choices, hence deepening their feelings of alienation and disaffection. 
$\ldots$ if there is a job it's very hard to get training in it. And then people just couldn't be bothered training you. (AP group)

Others expressed their antipathy for teachers who were considered inflexible, very strict and sometimes disrespectful.

I don't like teachers. [They] shouldn't be allowed to talk down to you. I slabber [talk back] at my teachers all the time for that because I don't like being disrespected by them. (YPP group)

Overall, formal education appeared not to have a significant influence in the lives of these young men, many of whom were stuck in the underachieving parts of the Northern Irish school system, which led to few opportunities in the labour market.

No-one goes to sixth form in this school or anything ... There's just child care. Would we want to go to child care? (PS group)

\section{Help-seeking behaviour}

The young men were asked to comment on the sources of help or services available in the area that might respond to their needs. Pejorative terms such as 'rubbish', 'crap' and 'boring' were used by the young men to characterise their lives in their communities.

It's c**p! There's nothing to do. You're bored out of your nut about five days a week and then it comes to the weekend ... and I'm still out of my nut. (PS group)

There was little evidence that these young men were aware of formal or informal services that might be available to them when they faced difficulties and stress. Some expressed the perils of sharing emotional problems with close relatives; this was often couched in narratives about gender and masculinity.

Women can talk to their ma and all that. You can't go saying anything and talking to your ma, like. She would only hit you a punch, like. I've never done it. (YS group)

A number of respondents thought that talking about worries or difficulties would make them a 'laughing stock' in front of their friends.

You could say it to your mate but your mate would just turn round and probably take the $\mathrm{p}^{* *} \mathrm{~s}$ out of you or something about it. A good laugh to him. And then you feel like a dick. (EOTAS group)

It appeared, however, that some young men were much more likely to turn to friends or peers at times of stress and personal difficulty.

[If you have problems, you] call your mates and have a wee drink. (AP group)

On the other hand, they were less likely to trust formal systems of help. For example, health and social care staff were occasionally mentioned by the young men as a source of support, but concerns were raised about confidentiality.

Social workers? I wouldn't associate with them. I wouldn't give them the time of day! They're just gazettes. They just go round and tell everybody your business. (AP group) 


\section{Concerns about suicide}

The young men in the study were asked to comment upon the reasons they attributed to suicides of young people that had occurred in their area. Three main reasons were highlighted: drug use and impulsivity, drug addiction and debt, and the consequences of emotional and psychological stressors. The following extract illustrates how these factors coalesced for one young man.

... you get into so much debt and then some night you just ... you're so high on cocaine and then you're like: 'F**g, I'll never be able to pay this', and then everything goes mad and then you kill yourself. (YS group)

The majority of respondents recognised the need to articulate negative feelings and emotions to be able to deal with them and find adequate solutions. Paradoxically, they tended not to be sympathetic to peers who had died or engaged in suicidal behaviour. These acts were thought to be cowardly, selfish and inconsiderate - revealing features of weaknesses in character which contradicted the predominant discourses of masculinity that pervaded many of the group interviews.

They're just cowards. That's probably it ... That's [suicide is] just the coward's way out if they're in trouble or something or somebody's after them. (AP group)

\section{Suggestions for change}

The suggestions for change proposed by the young men often focused on practical solutions to their problems, for example, in appeals for better leisure facilities with activities appropriate to their age group. Some acknowledged problems in emotional well-being, but were more likely to suggest the increased use of peer support and self-help groups that may allow them to talk more about their feelings, particularly in situations of elevated risk and suicide, as represented in the following extract.

Get other young boys who've already been through that [suicide attempts]. You should get them to help them, stuff like that. (EOTAS group)

They also pointed out to the importance of having a trusted person to talk to who may listen in a non-judgemental fashion and maintain confidentiality. Family and friends were mentioned as a main source of help, with other adults such as counsellors and youth workers also considered valuable in some circumstances.

Friends and family are important. Just people you can trust. (YPP group)

\section{Discussion}

The findings in this study provide a striking snapshot of the stark existence of socially excluded young men living in a semi-rural area in NI. In the last few years, society in NI, as in other parts of the UK, has been adversely affected by an economic recession that has been particularly damaging to the lives of vulnerable young people (McAlister and others, 2009; Northern Ireland Statistics and Research Agency, 2011). As argued above, it is important to explore the possible factors, structural as well as intra and interpersonal, that may explain 
these experiences (Levitas and others, 2007). A significant extra dimension is the impact of political conflict, which is reflected in some of the findings.

The young men appeared to experience social exclusion in a number of ways. There was a generalised pessimism about the perceived lack of leisure and employment opportunities in many of the stories we heard in the focus groups. Similarly, there was an ease of availability of alcohol and drugs, which appeared to contribute to risky and antisocial behaviours, leading to alienation from communities, health, social care, educational services and authority figures. The young men appeared to be desperately trying to make sense of the transition from childhood to the independence associated with adulthood in a climate of socioeconomic and political change, unsupported by education and employment and this is leading to impoverished lifestyles.

It is also possible to identify issues of gender and masculinity in some of these discourses. For example, explanations for aggression were often couched in the language of machismo (McGrellis, 2005). These views on masculinity also appeared to prevent help-seeking when young men became socially and psychologically vulnerable. These experiences of social exclusion, dispossession and deprivation may result in the denial of feelings and the creation of an emotional emptiness in their lives and relationships (Stephen and Squires, 2003).

Apart from these 'generic' factors that appear to explain the young men's experiences of social exclusion, we need to consider the impact of the political conflict when discussing the findings of this study. Although these behaviours are consistent with the general effects of unemployment, deprivation and poverty on young people in many other settings characterised by social exclusion, it is important to remember that these young men are negotiating their transition in a post-conflict society still tinted with deeply divided, segregated and sectarian environments that exacerbate their exclusion. Earlier we rehearsed some of the debates in the literature, which seek to establish, to a greater or lesser extent, the impact of the conflict on the lives of young people over the last four decades, as represented in the work of McAlister and others (2009), Leonard (2009) and McGrellis (2005) who have argued that the lives of many young people are shaped by sectarianism. Social, recreational and employment opportunities are often constricted by territorial boundaries that demarcate safe and not so safe spaces between communities. Some of these factors were evident in the way that some young men in the study described the risks and sometimes excitement during altercations with 'the other' at interface areas.

The lack of direction or a clear objective around the issue of the divided society, whether negative or positive, is likely to further fuel feelings of hopelessness and apathy towards the future. An alternative way of viewing the thoughts and feelings of the young men in the current study is to avoid the assumption that they are only committed to a life of toughness, crime and deprivation. Rather, they are facing uncertainty and disorientation where the patterns and norms of their parents are being replicated and structural conditions have further reinforced their exclusion. These factors, alongside others, may be at play when trying to explain and prevent the high numbers of young men who are represented in the increasing rates of suicide in NI (Tomlinson, 2007b).

\section{Conclusion}

If the views of the young men in this study reflect experiences of exclusion, then such findings present a series of challenges to policy-makers, practitioners and the wider society in NI 
as a whole. If such young men are to fully participate in and contribute towards community life to benefit from all the opportunities available, a more holistic approach to dealing with their needs and those of their communities is necessary. For example, the young men in this study consistently complained about the lack of leisure facilities appropriate to their age. It was clear that these gaps created many of the conditions that led to social isolation, addictions and vulnerability. Relevant agencies need to examine the range of leisure and activity services available in the area and ensure that age-appropriate programmes are considered. They must also be mindful of the style of services preferred by this age group, that is, appealing activities that allow them to access trusted adults in a confidential setting as a byproduct rather than a focus.

Preventative approaches are necessary to address the binge drinking that was endemic to many of the young men. There appeared to be many factors associated with this behaviour as an alternative form of leisure, a part of adolescent development and masculinity, along with wider societal attitudes. These should be further explored to develop adequate preventative programmes and initiatives. It is worth noting the value of evidence-based mental health promotion and early intervention programmes robustly evaluated in other jurisdictions like England, Scotland, the United States, Australia and Canada. Evaluated programmes with positive outcomes on the reduction of violence, substance abuse, emotional problems and other issues amongst children and young people include The UK Resiliency Programme, The Strengthening Families Program (SFP) and The Incredible Years Programme (Leavey and others, 2009). Perhaps most importantly, the voices of young people who have been marginalised and socially excluded need to be heard at a time of political and social change in NI, when there are raised expectations that the legacy of political conflict will be addressed (Davidson and Leavey, 2010; Office of the First Minister and Deputy First Minister, 2008).

\section{Study limitations}

There are a number of limitations to the study. First, the small sample does not allow for generalisations about the experiences of socially excluded young men. Secondly, the snowball sampling technique may have precluded the participation of a wider range of young men in the area. Third, given the sensitive issues explored, demographic details on religion or social class were not sought to retain participation. Nevertheless, the findings are consonant with other studies in the region including larger samples (urban and rural) and different sampling techniques (McAlister and others, 2009).

\section{Acknowledgements}

This research was sponsored by the legacy Southern Health and Social Services Board (SHEtSSB), Northern Ireland (quotation no. 101835/V0/Q07).

\section{References}

Bayliss J, Sly F. 2009. Children and young people around the UK. Regional Trends 41: 2-30. Office for National Statistics: London.

Becker HS. 1963. Outsiders: Studies in the Sociology of Deviance. Free Press of Glencoe; Collier-Macmillan: New York.

Bell D. 1987. Acts of union: youth sub-culture and ethnic identity amongst Protestants in Northern Ireland. The British Journal of Sociology 38: 158-183. 
Bradshaw J. 2011. The Wellbeing of Children in the UK, 3rd edn. The Policy Press: Bristol.

Cabinet Office. 2001. Preventing Social Exclusion. Report by the Social Exclusion Unit. Cabinet Office, Social Exclusion Unit: London.

Cabinet Office. 2006. Reaching Out: An Action Plan on Social Exclusion. Cabinet Office: London.

Campbell J, Rondón J, Galway K, Leavey G. 2011. Meeting the needs of vulnerable young men: a study of service provider views. Children \& Society. doi:10.1111/j.1099-0860.2011.00372.x.

Davidson G, Leavey G. 2010. Promoting mental health in Northern Ireland: addressing division, inequality and stigma. Journal of Public Mental Health 9: 6-15. doi:10.5042/jpmh.2010.0698.

Department of Education. 2010. Enrolments at Schools and in Funded Pre-School Education in Northern Ireland 2009/10. Department of Education (Northern Ireland), Statistics and Research Branch: Belfast

Department of Health, Social Services and Public Safety. 2006. Protect Life: A Shared Vision. Northern Ireland Suicide Prevention Strategy and Action Plan 2006-2011. Department of Health Social Services and Public Safety (Northern Ireland): Belfast.

Department of Health, Social Services and Public Safety. 2010a. Your Health Matters. The Annual Report of the Chief Medical Officer for Northern Ireland 2010. DHSSPS (Northern Ireland): Belfast.

Department of Health, Social Services and Public Safety. 2010b. Review of the Evidence Base for Protect Life - A Shared Vision. Northern Ireland Suicide Prevention Strategy. Final Report. DHSSPS (Northern Ireland): Belfast

Directgov. 2010. Crime and Justice. Anti-social Behaviour. Available at http://www.direct.gov.uk/en/ crimejusticeandthelaw/crimeprevention/dg_4001652 [Accessed 2 November 2010].

Directgov. 2012. Education and Learning. 16-19 Bursary. Available at http://www.direct.gov.uk/en/ EducationAndLearning/14To19/MoneyToLearn/16to19bursary/index.htm [Accessed 16 February 2012].

Faugier J, Sargeant M. 1997. Sampling hard to reach populations. Journal of Advanced Nursing 26: 790-797.

Finch H, Lewis J 2008. Focus groups. In Qualitative Research. A Guide for Social Science Students and Researchers. Ritchie J, Lewis J (eds.). Sage Publications Ltd.: London; 170-198.

Glaser BG, Strauss AL. 1967. Discovery of Grounded Theory: Strategies for Qualitative Research. Aldine Publishing Company: New York.

Griffiths P, Gossop M, Powis B, Strang J. 1993. Reaching hidden populations of drug users by privileged access interviewers: methodological and practical issues. Addiction 88: 1617-1626.

Hargie OD, Tourish D, Curtis L. 2001. Gender, religion, and adolescent patterns of self-disclosure in the divided society of Northern Ireland. Adolescence 36: 665-679.

Haydon D, Scraton P. 2008. Conflict, regulation and marginalisation in the north of Ireland: the experiences of children and young people. Current Issues in Criminal Justice 20: 59-78.

Hennink M, Diamond I. 1999. Using focus groups in social research. In Handbook of the Psychology of Interviewing. Memon A, Bull R (eds.). Wiley \&t Sons: London; 113-141.

Jenkins R. 1983. Lads, Citizens, and Ordinary Kids: Working-Class Youth Life-Styles in Belfast. Routledge \&t Kegan Paul: London, Boston.

Jones L, Allebone B. 1999. Researching 'hard-to-reach' groups: the crucial role of the research associate. International Journal of Inclusive Education 3: 353-362.

LeCompte MD, Goetz JP. Spring 1982. Problems of reliability and validity in ethnographic research. Review of Educational Research 52: 31-60.

Leavey L, Galway K, Rondón J, Logan G. 2009. A Flourishing Society: Aspirations for Emotional Health and Wellbeing in Northern Ireland: Northern Ireland Association for Mental Health: Belfast.

Leonard M. 2009. "It's better to stick to your own kind": Teenagers views on cross-community marriages in Northern Ireland. Journal of Ethnic and Migration Studies 35: 97-113.

Leonard M. 2010. Parochial geographies: growing up in divided Belfast. Childhood 17: 329-342. doi:10.1177/0907568210369216

Levitas R, Pantazis C, Fahmy E, Gordon D, Lloyd E, Patsios D. 2007. The Multi-Dimensional Analysis of Social Exclusion. Department of Sociology and School for Social Policy, Townsend Centre for the International Study of Poverty and Bristol Institute for Public Affairs, University of Bristol: Bristol. 
Lloyd K, Cairns E, Doherty C, Ellis K. 2008. Adolescent Mental Health in Northern Ireland. Empirical Evidence from the Young Life and Times Survey. In Young People in Post-Conflict Northern Ireland. The Past Cannot be Changed, but the Future can be Developed. Schubotz D, Devine P (eds.). Russell House Publishing Ltd.: Dorset; 17-27.

MacAloney K, McCrystal P, Percy A, McCartan C. 2009. Damaged youth: prevalence of community violence exposure and implications for adolescent well-being in post-conflict Northern Ireland. Journal of Community Psychology 37: 635-648.

McAlister S, Scraton P, Haydon D. 2009. Childhood in Transition. Experiencing Marginalisation and Conflict in Northern Ireland. Queen's University Belfast, Save the Children, The Prince's Trust: Belfast.

McCormick J, Harrop A. 2009. Devolution's Impact on Low-Income People and Places. Joseph Rowntree Foundation: York.

McGrellis S. 2005. Pure and bitter spaces: gender, identity and territory in northern Irish youth transitions. Gender and Education 17: 515-529.

New Policy Institute. 2009. Monitoring Poverty and Social Exclusion in Northern Ireland 2009. The Joseph Rowntree Foundation: York.

Northern Ireland Office. 1998. Good Friday Agreement. Belfast. Available at http://www.nio.gov.uk/ agreement.pdf [Accessed 10 November 2010]

Northern Ireland Statistics and Research Agency. 2010. Northern Ireland Multiple Deprivation Measure 2010. The Stationery Office: Belfast.

Northern Ireland Statistics and Research Agency. 2011. Key Statistics. Unemployment Rate, July 2011. Available at http://www.nisra.gov.uk/ [Accessed 5 December 2011].

Office for National Statistics. 2011. Statistical Bulletin: Labour Market. April. Office for National Statistics: Newport.

Office of the First Minister and Deputy First Minister. 2008. Lifetime Opportunities. Government's AntiPoverty and Social Inclusion Strategy for Northern Ireland. OFMDFM, Central Anti-Poverty Unit: Belfast.

O'Reilly D, Stevenson M. 2003. Mental health in Northern Ireland: have "the troubles" made it worse? Journal of Epidemiology and Community Health 57: 488-492.

South Tyrone Empowerment Programme. 2006. Literature Review. Black and Minority Ethnic Groups, Including Migrant Workers. Southern Investing for Health Partnership: Armagh, Northern Ireland.

Stephen DE, Squires PA. 2003. 'Adults don't realize how sheltered they are'. A contribution to the debate on youth transitions from some voices on the margins. Journal of Youth Studies 6: 145-164.

Tastsoglou E, Miedema B. 2003. Immigrant women and community development in the Canadian maritimes: outsiders within? The Canadian Journal of Sociology/Cahiers Canadiens De Sociologie 28: 203234.

Tomlinson M 2007a. The Trouble with Suicide. Mental Health, Suicide and the Northern Ireland Conflict: A Review of the Evidence. School of Sociology, Social Policy and Social Work, Queen's University Belfast: Belfast.

Tomlinson M. 2007b. Suicide and young people: the case of Northern Ireland. Child Care in Practice 13: 435-443.

Webster C, Simpson D, MacDonald R, Abbas A, Cieslik M, Shildrick T, Simpson M. 2004. Poor Transitions. Social Exclusion and Young Adults. The Policy Press: Bristol.

"Correspondence to: Janeet Rondón, Centre for Mental Health Research, Northern Ireland Association for Mental Health. 80 University Street, Belfast BT7 1HE, UK. E-mail: j.rondon@compasswellbeing.org

Accepted for publication 27 April 2012 